\title{
Effectiveness of Moringa oleifea Extract in Attenuating the Toxic Effect on Platelet Count: An Experiment on Cadmium Exposed
}

\section{Rats}

\author{
Vinodini NA', Pratik Kumar Chatterjee,**, Kunal', Suman VB', Rashmi KS', Nayanatara AK', Anupama N', \\ Ramesh M. Bhat ${ }^{1}$, Sheela Joice P $^{2}$
}

Vinodini NA' ${ }^{1}$, Pratik Kumar Chatterjee ${ }^{1, *}$, Kunal $^{1}$, Suman $\mathrm{VB}^{1}$, Rashmi KS ${ }^{1}$, Nayanatara $\mathrm{AK}^{1}$, Anupama N', Ramesh M. Bhat ${ }^{1}$, Sheela Joice $\mathrm{P}^{2}$

'Department of Physiology, Kasturba Medical College, Mangalore, Manipal Academy of Higher Education (MAHE), Manipal, Karnataka, INDIA.

${ }^{2}$ Department of Physiology, MES Medical College, Perinthalmanna, Kerala, INDIA.

\section{Correspondence}

\section{Pratik Kumar Chatterjee}

Associate Professor, Department of

Physiology, Kasturba Medical College,

Mangalore; Manipal Academy of Higher

Education (MAHE), Manipal, Karnataka,

INDIA.

E-mail: Pratik.chatterjee@manipal.edu

History

- Submission Date: 18-01-2019;

- Review completed: 27-03-2019;

- Accepted Date: 25-04-2019.

DOI : 10.5530/pj.2019.11.109

Article Available online

http://www.phcogj.com/v11/i4

Copyright

(C) 2019 Phcogj.Com. This is an openaccess article distributed under the terms of the Creative Commons Attribution 4.0 International license.

\begin{abstract}
Aims and Objective:To determine the role of Moringa oleifera on total platelet count alterations (T-PC) in rats treated with cadmium. Materials and Methods: In the present study female adult Wistar Albino rats, (180-200) gm were divided into, Group I-normal control, Group II-pretreated control, group III-cadmium treated, group IV- pre-treated with Moringa oleifera leaf extract (MOE) and then administered oral cadmium for a day, with $n=6$ each RESULTS : Indicate that the pre-treatment with $\mathrm{MOE}(100 \mathrm{mg} / \mathrm{kg} / \mathrm{bw})$ prior to cadmium infusion augmented the level of total platelet count $(p \leq 0.001)$ as compared to the cadmium-exposed group, which might have a role in clotting mechanisms also. Conclusion: Moringa oleifera extract has a beneficial effect on platelet count in cadmium-induced animal model.

Key words: Cadmium, Platelet count, Clotting mechanisms, Toxicity, Moringa oleifera.
\end{abstract}

\section{INTRODUCTION}

Cadmium $(\mathrm{Cd})$ is an environmental element with a broad range of applications in the industry. ${ }^{1}$ Cadmium has been identified as a carcinogen by International Agency for Research on Cancer/ IARC. ${ }^{2}$ It is mainly found in the environmental air and as a constituent of paint and is known to affect various blood parameters. ${ }^{3}$ Moringa oleifera, from Moringaceae family is a known hypotensive, anticancer, antibacterial agent. It is abundant in vitamins, minerals, phyto-nutrients such as carotenoids like carotene or pro-vitamins.

Cadmium contact can occur through the diet we consume, the water we drink or the fumes we inhale and often leads to changes in the antioxidant immune system in our body. ${ }^{4,5}$ Though the definite mechanisms of its associated toxicity are not yet well covered, there are reports on Cd remarkably enhancing the formation of reactive oxygen species (ROS), boosting lipid- peroxidation and cell-membrane damage and depleting the antioxidant defense elements in different body organs. ${ }^{6}$ It has been proved that after exposure, $\mathrm{Cd}$ attaches to red-cell membranes and binding to plasma protein it is transported to liver, where it bound to metallothionein/MT. ${ }^{7}$ Moreover, environmental presence of cadmium and other toxic metals has been directly linked to food contamination. ${ }^{8}$ The bioavailability, retention and toxicity of this environmental dangerous metal are affected by many factors, nutritional status such as low iron levels in the body. ${ }^{9}$ Hematology, the Science of blood, forms a crucial principle of various diagnostic procedures as it includes the examination of formed elements of the circulatory system..$^{10}$ Experimental evidences have shown that blood is one of the vital tissues having reproducible metabolic changes. Undue exposure to cadmium is harmful to human beings as it's passage via blood affects the blood parameters, including platelet count. ${ }^{11}$ Moringa oleifera is synonymously termed as the drumstick /horseradish tree, whereas in Nile valley, it is known as Shagara al Rauwaq. ${ }^{12}$ Numerous medicinal properties have been attributed to various parts of this scientifically valued tree. In South-Asia, practically entire plant has been used in traditional medicinal preparations for various health issues. It is believed that this particular medicinal preparation is highly effective for inflammation and infections, cardiac related ailments, digestive disorders, as well as liver diseases. It is one of the best natural coagulant discovered so far as it causes an increase in the platelet count. ${ }^{13}$ Although studies have shown that MOE battles cadmium induced metal intoxication, scientific literature is devoid of findings regarding the effect of MOE on the platelet count in cadmiumexposed rats. So, current experiments were designed to investigate the effect of MOE on total plateletcount on adult Wistar Albino rats exposed to cadmium.

\section{MATERIALS AND METHODS}

Reagents needed for the study were purchased from Durga Laboratories, Mangalore, Karnataka, India Institutional Animal Ethics Committee (IAEC) clearance was obtained prior to the research. All the experimental approaches and animal care were according to the recommendations of Institutional Animal Ethics Committee (IAEC).

\section{Plant materials}

Moringa oleifera leaves were collected from home grown areas in the shoreline of Karnataka, India and then authenticated by an expert botanist.

Cite this article: Vinodini NA, Pratik Kumar C, Kunal, Suman VB, Rashmi KS, Nayanatara AK et al. Effectiveness of Moringa oleifea Extract in Attenuating the Toxic Effect on Platelet Count: An Experiment on Cadmium Exposed Rats. Pharmacog J. 2019;11(4):689-93. 


\section{Extract preparation}

Plant extract preparation was done according to the previously published paper from the present laboratory. ${ }^{14}$

\section{Animals}

Twenty-four female Albino rats of albino strain of 4 months old (180$200 \mathrm{gms})$ were used for the present study. Food and water was provided ad libitum. Animals were categorized into 4 groups, $(\mathrm{n}=6)$.

\section{Hematological parameters}

Cardiac catheterization (23G needle) was used to collect the blood sample. About $4 \mathrm{~mL}$ of the blood was collected in an anti-coagulated tube. ${ }^{15}$ Total platelet count (T-PC) was performed using automated hematological analyzing techniques. ${ }^{16}$

\section{Statistical analysis}

Data represents mean \pm SEM. Statistical analysis was done by using ANOVA and post-test. Statistical significance was considered $\mathrm{p} \leq 0.05$.

\section{RESULTS}

In controls, total platelet count was found to be $6.41 \pm 0.06$. There was a significant decrease in platelet count $\left({ }^{* *} \mathrm{p} \leq 0.001\right)$ in group III $(4.50 \pm 0.14)$ compared to groups I and $\left({ }^{* *} p \leq 0.0001\right)$ group II $(6.73 \pm$ $0.10)$, whereas, group IV exhibited significant $\left({ }^{\star *} \mathrm{p} \leq 0.001\right)$ rise in total platelet count $(4.66 \pm 0.14)$ when compared with group III. Groups I and II didn't show any significant difference in platelet count (Tables 1 and 2).

\section{DISCUSSION}

Cadmium, a major contaminant of an environmental and industrial origin, carry a potential threat and affects multiple system in human and animals. ${ }^{17}$ Previous data suggest that blood is most important tissue in the body with reproducible metabolic alterations. Alterations in blood parameters are one of the most reliable toxicity markers of drugs and heavy metals. ${ }^{18}$ Earlier reports of blood clotting tests demonstrated that exposure to cadmium had resulted in hemostatic dys-regulation due to significant decrease in platelet-count. ${ }^{19}$ The present study which is in accordance with previous data, also showed a considerable reduction in TPC on cadmium exposure, which justifies the deadly effects of cadmium on blood components. A decline in T-PC could lead to extreme hematological disorders like purpura and leukemia. In severe conditions it may lead to death. ${ }^{20}$ Studies have shown that, liver is the major organ for synthesis of pro-coagulation factors and substances. ${ }^{21}$ The toxic effects of cadmium is generally due to its binding property to reactive agents. It results in the down regulation

Table 1: Study animals.

\begin{tabular}{crl}
\hline SI. No. & Groups & Characteristic features \\
\hline 1. & I & $\begin{array}{l}\text { Control (normal saline) } \\
\text { 2. }\end{array}$ \\
II & $\begin{array}{l}\text { Treated with the } M O E \text { aqueous leaf extract, }(100 \mathrm{mg} / \mathrm{kg} / \mathrm{bw}) \\
\text { orally, for } 10 \text { days }\end{array}$ \\
3. & III & $\begin{array}{l}\text { Administered cadmium chloride }(10 \mathrm{mg} / \mathrm{kg} / \mathrm{bw}) \text { orally } \\
\text { [Single dose] }\end{array}$ \\
4. & IV & $\begin{array}{l}\text { Pre-treated with the } M O E \text { extract }(100 \mathrm{mg} / \mathrm{kg} / \mathrm{bw}) \text { for } 10 \text { days } \\
\text { after which Cd }(10 \mathrm{mg} / \mathrm{kg} / \mathrm{bw}) \text { oral infusion for } 1 \text { day }\end{array}$ \\
\hline
\end{tabular}

Table 2: Effect of MOE on total platelet count in cadmium exposed rats.

\begin{tabular}{cc}
\hline Groups & Total platelet count \\
\hline I & $6.41 \pm 0.06$ \\
II & $6.73 \pm 0.10$ \\
III & $4.50 \pm 0.14$ \\
IV & $4.66 \pm 0.14$ \\
\hline
\end{tabular}

of enzymatic reactions, gene growth and reproduction. Cadmium stimulates lipid-peroxidation and the formation of reactive oxygen species (ROS), thus results in oxidative cellular and tissue-damage. ${ }^{22}$ It has been reported that, Cadmium augments adenylate-cyclase and hence hinders phospho-diesterase (PDE) activity. This in turn reduces the platelet-aggregation rate. ${ }^{23}$ Moringa oleifera is a multipurpose tree. ${ }^{24}$ It has various pharmacological properties that had been used in the treatment of innumerable disorders. ${ }^{25-27}$ Present findings reveal a clear rise in T-PC in rats pre-treated with MOE, prior to administration of $\mathrm{Cd}$, which may indicate the protective effect MOE against cadmium induced hem-toxicity. Nevertheless our findings are in agreement with the reports from previous studies. ${ }^{28}$ Thrombopoietin like substance may be present in the extract which in-turn has a vital role. ${ }^{29}$ Several studies reported that Moringa oleifera is one of the natural coagulant. ${ }^{13}$ It is also observed that that specific byproducts of these leaves has been found to have therapeutic potential. Hence used across the world claiming no side-effects. ${ }^{30}$ Present study confirms the potential of MOE in positively influencing the hemopoietic-system.

\section{CONCLUSION}

Current findings project that MOE has a remedial effect on cadmiuminduced toxicity to platelets in animal model. Further studies are needed to discover the detailed mechanisms triggering the present effects.

\section{ACKNOWLEDGEMENT}

We are thankful to the Department of Physiology, Kasturba Medical College (KMC), Mangalore, Manipal Academy of Higher Education (MAHE), Manipal, Karnataka, India, for providing the laboratory and necessary instruments for conducting the experiments.

\section{CONFLICTS OF INTEREST}

No conflicts of interest are declared

\section{ABBREVIATIONS}

MOE: Moringa olifera extract; Cd: Cadmium; T-PC: Total platelet count.

\section{REFERENCES}

1. Chatterjee PK, Anantharaya VN, Singhal A, Chatterjee P, Shiva RK, Mallya R Moringa oleifera aqueous leaf extract: Role on total leucocyte count and its differentials in cadmium toxicity in adult Wistar Albino rat model. National Journal of Physiology, Pharmacy and Pharmacology. 2016;6(2):119-22.

2. International Agency for Research on Cancer (IARC). Beryllium, cadmium mercury and exposures. In: glass manufacturing industryin monographs on the evaluation of carcinogenic risk San Diego, CA: Human Scientific Publications. 1993;58:119-237.

3. World Health Organization. Environmental Health Criteria, 134, Cadmium Geneva: World Health Organization, 1992;111-2.

4. Adedapo AA, Mogbojuri OM, Emikpe BO. Safety evaluations of the aqueous extract of the leaves of Moringa oleifera in rats. J Med Plants Res. 2009;3(8):586-91.

5. Vinodini NA, Chatterjee PK, Chatterjee P, Chakraborti S, Nayanatara AK, Bhat $\mathrm{RM}$, et al. Protective role of aqueous leaf extract of Moringa oleifera on blood parameters in cadmium exposed adult wistar albino rats. Int J Curr Res Acad Rev. 2015;3(1):192-4

6. Jamakala $\mathrm{O}$, Rani AU. Mitigating role of zinc and iron against cadmium induced toxicity in liver and kidney of male albino rat: A study with reference to metallothionein quantification. International Journal of Pharmacy and Pharmaceutical Sciences. 2014:6(9):411-17.

7. Bauman JW, Liu J, Klaassen CD. Production of metallothionein and heat shock proteins in response to metals. Fundamental and Applied Toxicology. 1993;21(1):15-22

8. Hounkpatin ASY, Edorh PA, Guédénon P, Alimba CG, Ogunkanmi A, Dougnon TV, et al. Haematological evaluation of wistar rats exposed to chronic doses of cadmium, mercury and combined cadmium and mercury. Afr J Biotechnol. 2013;12(23):3731-37. 
9. Mallya R, Chatterjee PK, Vinodini NA, ChatteRjee P, MithRa P. Moringa oleifera leaf extract: Beneficial effects on cadmium induced toxicities-A review. Journal of clinical and diagnostic research (JCDR). 2017;11(4):CE01.

10. Asomugha AL, Ezejindu DN, Asomugha RN, Anyabolu AE, Ojukwu PC. Evaluation of toxicity effect of graded doses of Moringa oleifera leaf extract on blood indices using 20 adult wistar rats. Int J Biomed Adv Res. 2015;6(2):98102

11. Ashour TH. Preventative effects of caffeic acid phenyl ester on cadmium intoxication induced hematological and blood coagulation disturbances and hepato-renal damage in rats. ISRN Hematology. 2014:1-7.

12. Sarvesh K, Kumar MS, Kumar SASA. Quality control standardization of the bark of Moringa Oleifera Lam. International Journal of Pharmacy and Pharmaceutical Sciences. 2015;7(1):56-60.

13. Archibong AN, Nku CO, Ofem OE. Extract of Moringa oleifera attenuates hematological parameters following salt loading. MicroMedicine. 2017;5(1):2430.

14. Mukherjee P. Extraction of herbal drugs. In: quality control on herbal drugs. An approach to evaluation of botanicals, $1^{\text {st }}$ edn. Chapter 11.New Delhi, India: Business Horizons, 2002;371-425.

15. Ghai CL. A Textbook of Practical Physiolog, $8^{\text {th }}$ Edition. New Delhi, India: Jaypee Brothers Medical Publishers (P) Ltd, 2013;111-127.

16. Coles EH. Veterinary clinical pathology. Philadelphia, PA: WB Saunders, Co, 1986.

17. Jarup $L$, Akesson $A$. Current status of cadmium as an environmental health problem. Toxicology and applied pharmacology. 2009;238(3):201-8.

18. Lodi S, Kansala L. Antioxidant activity of rubia cordifolia against lead toxicity. Int J Pharmaceut Sci Res. 2012;3(7):2224-32.

19. Amitrano L, Guardascione MA, Brancaccio V, Balzano A. Coagulation disorders in liver disease. Seminars in Liver Disease. 2002;22(1):83-96.

20. Guyton AC, Hall JE. Textbook of Medical Physiology. $10^{\text {th }}$ edn. W. B. Saunders, Philadelphia, 2004:345-.56

21. Korish AA. Effect of caffeic acid phenethyl ester on the hemostatic alterations associated with toxic-induced acute liver failure. Blood Coagulation and Fibrinolysis. 2010;21(2):158-63.

22. Hambach R, Lison D, Haese PCD. Co-exposure to lead increases the rena response to low levels of cadmium in metallurgy workers. Toxicology Letters. 2013;22(2):233-8.

23. Kumar SV, Bhattacharya S. In Vitro toxicity of mercury, cadmium and arsenic to platelet aggregation: Influence of adenylate cyclase and phosphodiesterase activity. In Vitro Mol Toxicol. 2000:13:137-144.

24. Chatterjee PK, Vinodini NA, Amemarsoofi A, Nayanatara AK, Pai SR, Suman VB. Hypolipidemic effect of Moringa oleifera leaf extract in cadmium exposed rats. International Journal of Innovative Research in Science, Engineering and Technology. 2013;2(9):4718-23.

25. Asomugha AL, Ezejindu DN, Asomugha RN, Anyabolu AE, Ojukwu PC Evaluation of toxicity effect of graded doses of Moringa oleifera leaf extract on blood indices using 20 adult wistar rats. Int J Biomed Adv Res. 2015:6(2):98 102.

26. Goyal BR, Agarwal BB, Goyal RK, Mehta AA. Phyto-pharmacology of Moringa oleifera Lam.ó-An overview. Nat Prod Radiance. 2007;6(4):347-53.

27. Otitoju O, Nwamarah JU, Otitoju GTO, Okorie AU, Stevens C, Baiyeri KP. Effect of Moringa oleifera aqueous leaf extract on some haematological indices in wistar rats. Chem Process Eng Res. 2014;18:26-30.

28. Anwar F, Latif S, Ashraf M, Gilani A. Moringa oleifera: A food plant with multiple medicinal uses. Phytother Res. 2007;21(1):17-25

29. Erslev AJ, Gabuzda TG. Pathophysiology of Blood P3 and P41. Saunders, Philadelphia, 1979

30. Babu E, Basu D. platelet large cell ratio in the differential diagnosis of abnormal platelet counts. Ind J Pathol Microbiol. 2004;47(2):202-5.

\section{SUMMARY}

\section{GRAPHICAL ABSTRACT}

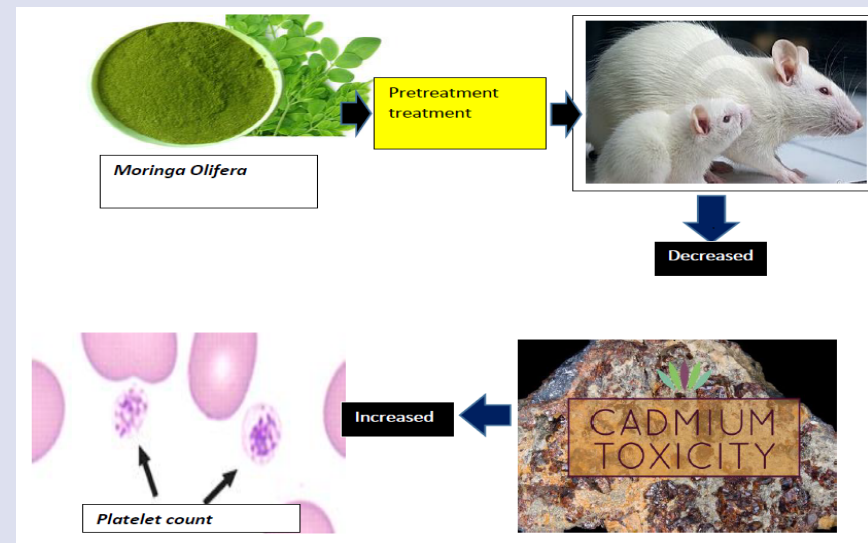

Cadmium $(\mathrm{Cd})$ exposure produces alterations in the platelet count. MOE has a remedial effect on this toxicity. Hence, this study showed potential of MOE in positively influencing the hemopoietic-system.

\section{ABOUT AUTHORS}

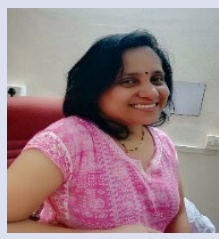

Dr. Vinodini NA: I had obtained my Ph. D. degree from Manipal Academy of Higher Education Manipal, and currently working as Associate professor in the department of physiology Kasturba Medical college Mangalore Karnataka. My field of research interest is toxicology, reperfusion injury and cancer and to find out preventive as well as therapeutic solutions from different plant sources. I have received best paper award in an international conference organized by IISRO held at Pattaya and having more than 40 papers to my credit. 


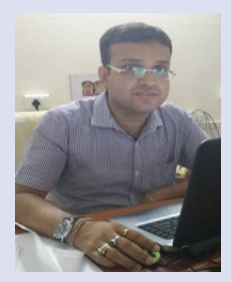

Dr. Pratik Kumar Chatterjee: He has obtained his MBBS degree from Manipal College of Medical Sciences (MCOMS), Pokhara, Kathmandu-University (KU), Nepal, in the year 2006 and consequently MD (Physiology) from Kasturba Medical College (KMC), Manipal Academy of Higher Education (MAHE), Manipal, Karnataka, India, in the year 2010. He has completed Post graduate diploma in Bioethics and Medical ethics (PGDBEME), from Yenepoya Medical College, Mangalore, Karnataka, India, in the year 2019. He also possesses Professional Diploma in Clinical Research (PDCR) from Catalyst Clinical Services Pvt. Ltd., Delhi, India, in the year 2013. Dr. Pratik Kumar Chatterjee is a Fellow of Association of General Education (FAGE), from Manipal Academy of Higher Education (MAHE), Manipal, Karnataka, India, from 2010 onwards. He is currently working as Associate-Professor, Kasturba Medical College (KMC), Mangalore, Manipal Academy of Higher Education (MAHE), Manipal, Karnataka, India. His field of interest is toxicology, diabetes \& cancer. He has attended \& presented papers at various national \& international conferences, Continued Medical Education (CME) programs, Workshops, Faculty Development programs \& has chaired sessions in Continued Medical Education (CME) programs also. He has been a member of Board of Studies (BOS) for MBBS curriculum, Manipal Academy of Higher Education (MAHE), Manipal, Karnataka, India, the year 2011 \& 2017 respectively. He has more than 20 papers to his credit \& has been awarded certicate of appreciation for contribution to research Manipal Academy of Higher Education (MAHE), Manipal, Karnataka, India in the year 2012, 2013, 2014 and is a recipient of Ist prize in Audio-Visual Self Learning Material, Manipal Academy of Higher Education (MAHE), Manipal, Karnataka, India in the year 2015. Dr. Pratik Kumar Chatterjee has also been conferred with the 'Good Teacher Award', Kasturba Medical College (KMC), Mangalore, Manipal Academy of Higher Education (MAHE), Manipal, Karnataka, India, in the year 2016.

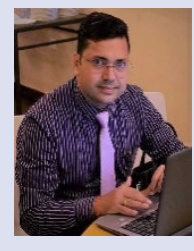

Dr. Kunal: He obtained his MBBS and MD from Kasturba Medical College (KMC), Mangalore, Manipal Academy of Higher Education Manipal, Karnataka, India and currently he is working as Associate professor in the department of physiology Kasturba Medical college (KMC), Mangalore, Manipal Academy of Higher Education (MAHE), Manipal, Karnataka, India. His field of interest is yoga.

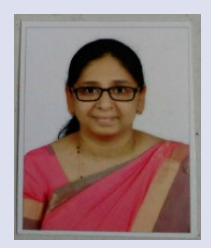

Dr. Suman VB: completed MD in Physiology from Kasturba Medical College, Mangalore, Affiliated to Manipal Academy of Higher Education, Karnataka, India, in 2009. She has over 10 years of academic teaching, clinical teaching and research experience. Has received STS (Short Term Studentship) Research grant in 2013 from ICMR. She has more than 25 research articles in peer reviewed indexed international journals. She has also published books and book chapters on various topics. Her areas of research include clinical epidemiology of Osteoporosis, Nano toxicity, work stress in working women etc.

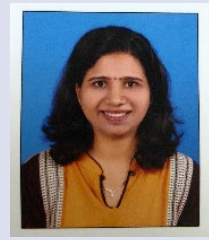

Dr. Rashmi K S: Working as an Assistant Professor in the Dept. of Physiology, KMC, Mangalore. She has more than 20 Publications in her credit. She has more than $15 \mathrm{National}$ and International conference presentations. She has received several travel grants by International Brain Research Organization (IBRO) to attend various international neuroscience meetings. She was a Co-investigator for the project titled "A study of role of Nucleus Accumbens and related subcortical centers in addictive and consummatory behavior of male Wistar albino rats" which was funded by DBT, Govt. of India. 


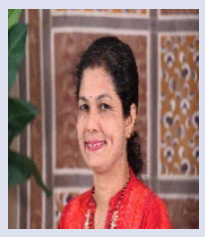

Dr. Nayanatara Arun Kumar is currently working as an Associate Professor of Physiology, Kasturba Medical College Mangalore, Manipal Academy of Higher Education. She is a recognized Ph.D guide of Manipal Academy of Higher Education. At present, she is guiding 3 Ph.D students Her research area is mainly focused on stress, Radioprotective effects of herbal extracts, neurophysiology, stress, food additives and alcohol. She has more than 95 research publications in indexed journals. She has been working as a Principal Investigator for BRNS funded project. She has been awarded the prestigious VGST Award for Research Publications (ARP) 2017-18 in the field of Medical and Life Science by Government of Karnataka, Vision Group on Science and Technology (VGST).

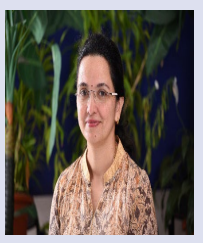

Dr Anupama N: Completed my graduation in MD Physiology in Kasturba Medical College, Mangalore, Karnataka in 2004 and at presently working as Associate Professor in Dept of Physiology. My field of research is respiratory medicine as I have done my MD dissertation in the same.

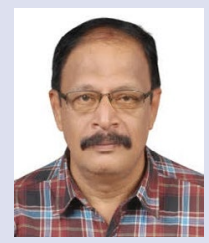

Dr. Ramesh M Bhat: MD in Physiology, presently working as Professor in Dept. of Physiology, Kasturba Medical College (KMC), Mangalore, Manipal Academy of Higher Education (MAHE), Manipal, Karnataka, India. His research experience is in the field of 'Cardio- respiratory physiology" for the last 29 years. He was the former Head of the department of Physiology and is a recognized MD and Ph.D guide of Manipal Academy of Higher Education (MAHE), Manipal, Karnataka, India.

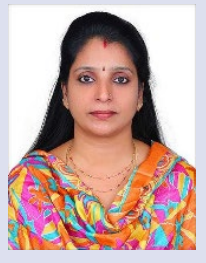

Dr. P Sheela Joice: Asst Professor in Dept of physiology at VMKV Medical college, Salem. I am an academician and researcher at Vinayaka Missions University. My Primary area of research was on Yoga, currently doing research on Biological Vascular age in diabetic and hypertensive subjects. I have done national and international publications on yoga related studies.

Cite this article: Vinodini NA, Pratik Kumar C, Kunal, Suman VB, Rashmi KS, Nayanatara AK, et al. Effectiveness of Moringa oleifea Extract in Attenuating the Toxic Effect on Platelet Count: An Experiment on Cadmium Exposed Rats. Pharmacog J. 2019;11(4):68993. 